\title{
Decrease of BCL-2 Expression by Ethanol Extract of Ocimum Basilicum L. Leaves in Breast Cancer Cells
}

\author{
Devi Nisa Hidayati ${ }^{1 *}$, Fatimatuz Zahroh ${ }^{1}$, Lina Wahyuni ${ }^{1}$, Ibrahim Arifin ${ }^{1}$ \\ ${ }^{1}$ Faculty of Pharmacy, Universitas Wahid Hasyim, Semarang, Indonesia \\ *Correspondence email : devinisahidayati@yahoo.com
}

\begin{abstract}
Ocimum basilicum $\mathrm{L}$ has proven to have in vitro cytotoxic activity against breast cancer cells. Pathways that cause cell death can involve one of the proteins, which is BCL-2. This study aims to determine the decrease of BCL-2 protein expressions in breast cancer cells (T47D and MCF-7) that are treated with the ethanol extract of Ocimum basilicum L. Ocimum basilicum L. was extracted using the maceration method with $70 \%$ ethanol solvent. The concentration of ethanol extract of Ocimum basilicum L. used to see the expression of BCL-2 protein in T47D and MCF-7 cells was $199 \mu \mathrm{g} / \mathrm{ml}$ and $388 \mu \mathrm{g} / \mathrm{mL}$. The observation of BCL-2 protein expression is using immunocytochemical methods of T47D and MCF-7 cancer cells. The results showed that the ethanol extract of Ocimum basilicum $\mathrm{L}$ could reduce BCL-2 protein expression in breast cancer cells (T47D and MCF-7) at concentrations of $199 \mu \mathrm{g} / \mathrm{ml}$ and $388 \mu \mathrm{g} / \mathrm{ml}$, respectively.
\end{abstract}

Keywords: Ocimum basilicum L; BCL-2; T47D; MCF-7

\section{INTRODUCTION}

Breast cancer is cancer that still occurs relatively high in the world. ${ }^{1}$ In 2018 , the prevalence of breast cancer in Indonesia was relatively high; there were 58,256 new cases and 22,692 deaths. ${ }^{2}$ Various cancer treatments have been carried out, including surgery, chemotherapy, radiotherapy, and therapy with monoclonal antibodies. One of the treatments uses a chemotherapy agent, doxorubicin. However, the use of doxorubicin tends to cause toxic side effects in normal tissues and cancer cell resistance. ${ }^{3}$ Efforts in treating cancer are now constantly being developed because there are no specific drugs capable of killing cancer cells. Unfortunately, current treatments still show side effects on normal cells. ${ }^{3}$ Natural product, predominantly plants, are considered to have lower side effects, so that natural drug-based medications are always being developed.
Ocimum basilicum $\mathrm{L}$. is a plant that has anticancer activity in breast cancer cells. ${ }^{4}$ Ocimum basilicum contains active ursolic acid compounds that can inhibit cells proliferation. ${ }^{5}$ Ocimum basilicum has been proved to contain active flavonoids, saponins, essential oils and tannins which are known to inhibit BCL-2 expression. ${ }^{6,7}$

An anti-apoptotic protein, which is BCL2 , is expected to decrease apoptosis. BCL-2 protein is a protein that plays an important role in the regulation of apoptosis. ${ }^{8}$ Based on the background above, it is necessary to develop research to identify potential natural materials as anticancer by testing them into one of the mechanisms that block the BCL-2 protein inhibition that can trigger the apoptosis of the cell. So, it is important to know the decline of the BCL-2 expression by the ethanol extract of Ocimum basilicum L. on breast cancer (T47D and MCF-7).

MATERIAL AND METHODS 
The tools used in this study were dryer cabinets, moisture balance, set of maceration tools, scale and pigetic blower (Heildolph), flow cabinet (LAF), $\mathrm{CO}_{2}$ incubator (Heraceus), microscope, 6-well plate (Nunc), and Haemocytometer (Neubauer).

The materials used in this study were Ocimum basilicum L. leaves (from Bandungan, Semarang district), 70\% ethanol, T47D and MCF-7 cell lines (Parasitology Laboratory of FK UGM), DMEM media, DMSO, primary antibodies against BCL-2. (Dako), Streptavidin, Secondary IgG biooncology antibodies, Hematoxylin, 3.3 Chromosome-diaminobenzidine (DAB).

Plants' determination of Ocimum basilicum L. was conducted at the Faculty of Mathematics and Natural Sciences Diponegoro University. The determination was done by matching plant morphology with reference books.

The making of the ethanol extract of Ocimum basilicum L: The dried leaves of Ocimum basilicum L. with less than $10 \%$ water content were pollinated. Then, a maceration process on the Ocimum basilicum L. leaf powder was carried out for 5 days ( 3 days of maceration, 2 days of re-maceration) using $70 \%$ ethanol solvent. The ratio of the amount of powder and solvent is 1:10). The macerate and re-maceration results were combined and converted into a viscous extract using a rotary vacuum evaporator $\left(\mathrm{T}: 50^{\circ} \mathrm{C}\right)$.

Immunocytochemical test concentration: The rationale for using the concentrations used was the IC50 value of the ethanol extract of Ocimum basilicum L. against T47D and MCF-7 cells. The IC50 value is a concentration that can inhibit $50 \%$ of cancer cells in the cytotoxic test. The IC50 values obtained from previous studies on T47D and MCF-7 cells were $399.86 \mu \mathrm{g} / \mathrm{mL}$ and 387.76 $\mu \mathrm{g} / \mathrm{mL}$, respectively. ${ }^{4}$ Where in the immunocytochemical test, the concentration of the ethanol extract of Ocimum basilicum $\mathrm{L}$. used was half of the IC50 $(199 \mu \mathrm{g} / \mathrm{mL}$ on T47D cells) and IC50 (388 $\mu \mathrm{g} / \mathrm{mL}$ on MCF-7 cells).

T47D and MCF-7 cell preparation. The cells in the cryotube were taken from the liquid nitrogen tank, followed by thawing at $37^{\circ} \mathrm{C}$ and sprayed with alcohol. The cells were transferred to a sterile conical tube in which DMEM media was present. The cells were then centrifuged for 10 minutes until the supernatant and pellets emerged. The supernatant was discarded, while the pellets were added $10 \mathrm{~mL}$ of growth medium (containing 10\% FBS). After becoming homogeneous, divide it into two tissue culture dishes (TCD) at $37^{\circ} \mathrm{C}$ in a $\mathrm{CO} 2$ incubator. Cells were grown to confluent so that they can be used for research.

Harvesting of T47D and MCF-7 cells: The cells which were confluent and sufficient for the study were discarded and then washed with PBS. Cells attached to TCD were removed by adding trypsin-EDTA. If the cells have been removed, add DMEM media. The suspension was centrifuged, and the supernatant was discarded. Then, culture media was added to the pellets, and the number of cells was counted using a hemocytometer under an inverted microscope. The cell suspension was transferred into a sterile conical tube according to the number of cells used for immunocytochemical testing.

Immunocytochemical test: testing was performed using T47D cell density $\left(1 \times 10^{5}\right.$ cells/well) and MCF-7 cells $\left(5 \times 10^{4}\right.$ cells/well). Different cells were treated using different 6-well plates. Each well was planted with $1000 \mu \mathrm{L}$ cells. Culture media $(100 \mu \mathrm{L})$ was added after the cells were attached to the coverslip, then the plates were incubated for 24 hours in a $\mathrm{CO} 2$ incubator. After 24 hours, the media was taken out, washed with PBS, and the extract was added at concentrations of $388 \mu \mathrm{g} / \mathrm{mL}$ (MCF-7 cells) and $199 \mu \mathrm{g} / \mathrm{mL}$ (T47D cells), followed by re-incubating for 24 hours. Preparate was followed by fixation and incubated in a freezer $-4{ }^{\circ} \mathrm{C}$ for 10 minutes. The cells in the coverslip were removed and placed on a $6 \mathrm{~cm}$ dish and washed with distilled water, then dripped with hydrogen peroxidase blocking solution (10 minutes) at room temperature, then discarded. Preparate was incubated with prediluted blocking serum (10 minutes), followed by 
dripping with anti-Bcl-2 Monoclonal Primary Antibody (1:50 dilution) on T47D/ MCF-7 cells for 24 hours at $4^{\circ} \mathrm{C}$, and washed with PBS. The microscope slides were sequentially incubated in a biotinylated universal secondary antibody (10 minutes), streptavidin-peroxidase complex reagent (10 minutes), and DAB substrate solution (2-10 minutes). Afterward, the slides were washed, and soaked in Mayer Haematoxylin (1-3 minutes) for further counterstain washing, followed by dipping the xylol, dripped with mounting media, and covered with a microscope slide cover. Finally, protein expression was observed under a light microscope with a magnification of 100$1000 \mathrm{x}$ and control cells were treated similarly. ${ }^{9}$

\section{Analysis}

BCL-2 protein expression was observed by immunocytochemical staining using BCL-2 antibody. Observations were made qualitatively using a light microscope. Cells with positive expressions will have brown cytoplasm, while cells with negative expressions will have purple or blue cytoplasm. A positive control is given primary antibodies to appear the brown cytoplasm. ${ }^{17}$

\section{RESULTS}

Plant determination is the initial step that must be carried out if a study uses natural ingredients. The determination aims to determine that the plant identity used is correct by comparing the plant morphology with reference books. The results showed the keys of determination and stated that the plant used is Ocimum basilicum L.

The leaves of Ocimum basilicum L. were transformed from dried form to leaf powder to expand the contact surface with the solvent, thereby facilitating the solubility of the compound with the solvent. ${ }^{16}$ The ethanol extract of Ocimum basilicum L. has cytotoxic activity against T47D and MCF-7 cells with IC50 values of $399.86 \mu \mathrm{g} / \mathrm{mL}$ and 387.76 $\mu \mathrm{g} / \mathrm{mL}$, respectively. ${ }^{4}$ Another study related to the cytotoxic test of the methanol extract of
Ocimum basilicum L. In MCF-7 cells showed an IC50 of $98.51 \mu \mathrm{g} / \mathrm{mL}$. This showed that the difference wass possible because the solvent used was different. Methanol solvent can attract higher levels of flavonoids than ethanol solvent. ${ }^{14}$ However, from a safety point of view, ethanol solvent is less toxic than methanol. The concentration reference used was the study of the ethanol extract of Ocimum basilicum L cells T47D and MCF-7 with $\mathrm{IC}_{50}$ values of $399.86 \mu \mathrm{g} / \mathrm{mL}$ and 387.76 $\mu \mathrm{g} / \mathrm{mL}$, because the solvent and materials used came from the same place. ${ }^{4}$

The immunocytochemical test is a test to observe the expression of the BCL-2 protein. It has been proven that the effect of Ocimum basilicum L. ethanol extract has anticancer activity against T47D and MCF-7 cells. ${ }^{4}$ The methanol extract of Ocimum basilicum L. possessed cytotoxic activity against MCF-7 cells. ${ }^{10}$ Similar research on the methanol extract of Ocimum basilicum L. stated that the extract was able to stimulate the death of MCF-7 cells. ${ }^{5}$ Therefore, it is necessary to investigate whether cell death (apoptosis) due to the treatment of Ocimum basilicum L. ethanol extract can affect and through a decrease in the antiapoptotic protein, namely BCL-2.

Immunocytochemical testing was carried out at the IC50 value obtained in the previous cytotoxic test, which is a concentration that can kill $50 \%$ of cells. According to Fitriasih et al, the concentrations that can be used in immunocytochemical testing are 1/4 IC50, 1/2 IC50, and IC50. ${ }^{17}$ However, in this study, we only wanted to see which concentration began to show a decrease in $\mathrm{BCl}-2$ expression. So, the concentration of the ethanol extract of Ocimum basilicum L. used was half of the $\mathrm{IC}_{50}(199 \mu \mathrm{g} / \mathrm{mL}$ on T47D cells $)$ and $\mathrm{IC}_{50}(388$ $\mu \mathrm{g} / \mathrm{mL}$ on MCF-7 cells). Immunocytochemical testing was performed on MCF-7 cells because these types of cells had BCL-2 overexpression characteristics. ${ }^{11}$ BCL-2 protein is one of the anti-apoptotic proteins, meaning that the increase in this protein inhibits apoptosis or increases cell survival. ${ }^{8,12}$ Immunocytochemical test results for the ethanol extract of Ocimum basilicum 
L. (EEOB) on T47D cells (Figure 1) and MCF-7 cells (Figure 2).
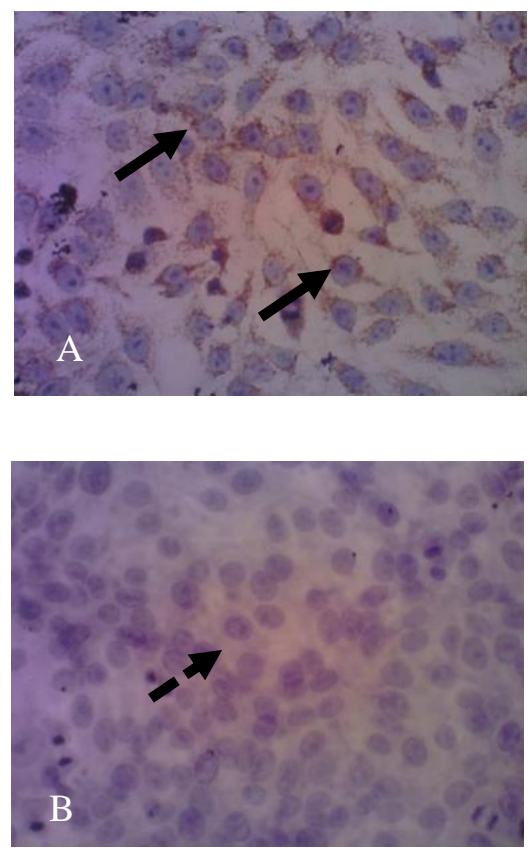

Figure 1. Effects of Ocimum basilicum L ethanol extract treatment on BCL-2 expression in T47D cells. Positive control of cells with anti-BCL-2 (A) primary antibody staining, EEOB concentration of $199 \mu \mathrm{g} / \mathrm{mL}$ $(\mathrm{B}), \rightarrow$ positive BCL-2 expression, ----> negative BCL-2 expression.

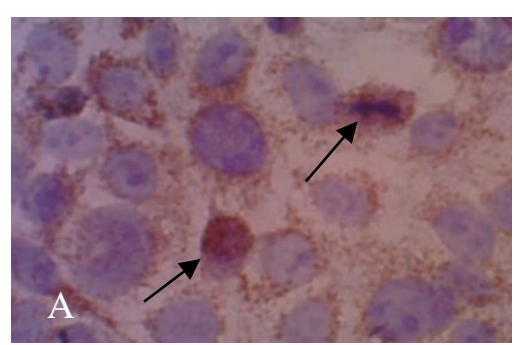

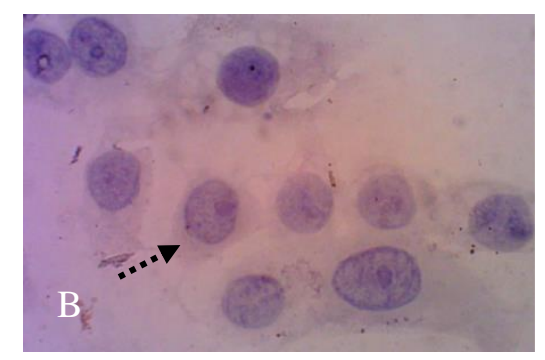

Figure 2. Effects of Ocimum basilicum L ethanol extract treatment on BCL-2 expression in MCF-7 cells. Positive control of cells with anti BCL-2 (A) primary antibody staining, EEOB concentration $388 \mu \mathrm{g} / \mathrm{mL}$ (B), $\rightarrow$ positive BCL-2 expression, ---> negative BCL-2 expression

\section{DISCUSSION}

The observation of the BCL-2 protein expressions was done by the immunocytochemical method, in which the principle uses specific antibody binding. Cells showed a brown color when expressing protein and purple when expressing no protein. Figure $1 \mathrm{~B}$ and $2 \mathrm{~B}$, compared to $1 \mathrm{~A}$ and $2 \mathrm{~A}$, showed the expression of BCL-2 that experienced a decrease after treatment of ethanol Ocimum basilicum $\mathrm{L}$ extract. The decreased expression of BCL-2 after ethanol Ocimum basilicum L extract treatment was visible because it showed blue cell cytoplasm compared to the controls that looked browner. This suggested that the ethanol extract of Ocimum basilicum L. could reduce BCL-2 protein expression in (T47D and MCF-7) breast cancer cells.

Ocimum basilicum had been proven to have active flavonoids, saponins, essential oils, and tannins. ${ }^{6}$ Flavonoids were reported to be able to stimulate apoptosis by several mechanisms, including inhibition of DNA topoisomerase I / II, decreased BCL-2 and $\mathrm{BCL}-\mathrm{XL}$, and increased expression of Bax and Bak genes (13). BCL-2 protein was one of the proteins involved in the apoptosis process. ${ }^{8}$ The suppression of BCL-2 protein expression could induce apoptosis induction 
through the release of cytochrome $\mathrm{c}$ by entering the outer mitochondrial membrane that could then activate the caspase pathway. Mitochondrial cytochrome $\mathrm{c}$ together with Apaf- 1 and protease 9 formed the apoptosome complex. The formation of apoptosomes would result in an auto-activation of caspase 9 and would activate caspase 3 . This was what could cause cancer cells to experience apoptosis. ${ }^{18}$ This research is still in qualitative form, therefore, further quantitative research is needed to see how much BCL-2 inhibition is caused by giving Ocimum basilicum $\mathrm{L}$. ethanol extract and confirms the pathway that is considered to play a role in increasing apoptosis in T47D and MCF-7 cells.

\section{CONCLUSION}

Studies have shown that ethanol extract of Ocinum basilicum $\mathrm{L}$ was able to reduce the expressions of BCL-2 protein in breast cancer cells (T47D and MCF-7) at concentrations of $199 \mu \mathrm{g} / \mathrm{ml}$ and $388 \mu \mathrm{g} / \mathrm{ml}$, respectively.

\section{REFERENCES}

1. Pusat Data dan Informasi Kemenkes. (2015). Stop Kanker. Jakarta: Departemen Kesehatan

2. Globogan. (2018). International Agency or Research on Cancer. http://gco.iarc.fr/today/data/factsheets/ca ncers/20-Breast-fact-sheet.pdf. diakses tanggal 27 Agustus 2020

3. Xu, F., Wang, F., Yang, T., Sheng, Y., Zhong, T., and Chen, Y. (2014). Differential Drug Resistance Acquisition to Doxorubicin and Paclitaxel in Breast Cancer Cells, Cancer Cell Internasional, 14(142), 1-13. DOI

4. Hidayati DN, Arifin I, Zahroh F, Wahyuni L. (2019). Efek Sitotoksik Ekstrak Etanolik Ocimum basilicum L. Pada Sel Kanker Payudara. Jurnal Pharmascience. 6(2):74-79. http://dx.doi.org/10.20527/jps.v6i2.7353

5. Qamar KA, Dar A, Siddiqui BS, Kabir N, Aslam H, Ahmed S, Erum S, Habib S, and Begum S, (2010). Anticancer Activity of Ocimum basilicum and the Effect of Ursolic Acid on the Cytoskeleton of
MCF-7 Human Breast Cancer Cells. Letters in Drug Design and Discovery. 7:726-736.

$10.2174 / 1570180811007010726$

6. Depkes RI. (2001). Inventaris Tanaman Obat Indonesia (1) jilid 2. Jakarta: Departemen Kesehatan dan Kesejahteraan Sosial Republik Indonesia

7. Raju and Rao. (2004). Diosgenin a Steroid Saponin of Trigonella Foenum Graceum (Fenugreek) Inhibits Azoxymethane Induced Aberrant Crypt Foci Fomation in F344 Rats and Induces Apoptosis in HT29 Human Colon Cancer Cells. Cancer Epidemiology Biomarker and Prevention. 13: 1392. PMID: 15298963

8. Simstein R, Burow M, Parker A, Weldon C, and Beckman B. (2003) Apoptosis, Chemoresistance, and Breast Cancer: Insights from The MCF7 Cell Model System. Exp Biol Med. 228:995-1003. DOI: $10.1177 / 153537020322800903$

9. Cancer Chemoprevention Research Center. (2009). In Vitro Test Protocol. Available at http://ccrc.farmasi.ugm.ac.id. (12 Agustus 2016).

10. Al-Ali KH, Beshbishy HSE, Badry AAE, and Alkhalaf M. (2013). Cytotoxic Activity of Methanolic Extract of Mentha Longifolia and Ocimum basillicum Against Human Breast Cancer. Pakistan Journal of Biological Science. 10:10288880. DOI: $10.3923 /$ pjbs.2013.1744.1750

11. Weigert A, Tziepy N, Knethen A, Johann A, Schmidt H, Geisslinger G, and Brune B. (2007). Tumor Cell Apoptosis Polarizes Macrophages-Role of Sphingosine-1-Phosphate. Molecular Biology of the Cell. 18(10): 3810-3819. doi: 10.1091/mbc.E06-12-1096

12. Marleen FS, Syahruddin E, Hudoyo A, Endarjo S, Hidayat $\mathrm{H}$, and Suzanna E. (2008). Ekspresi protein Bcl-2 pada sediaan blok parafin jaringan kanker paru. Jakarta: Departemen Pulmonologi \& Ilmu Kedokteran Respirasi FKUI

13. Ren W, Qiao Z, Wang H, Zhu L, and Zhang L. (2003). Flavonoids: Promicing Anticancer Agents. Med Res Rev. 23 (4):519-534. DOI: $10.1002 / \mathrm{med} .10033$ 
14. Zulharmitta, Elrika D, dan Rivai $H$. (2010). Penentuan Pengaruh Jenis Pelarut Ekstraksi Terhadap Perolehan Kadar Senyawa Fenolat dan Daya Antioksidan dari Herba Meniran (Phyllanthus niruri L.,). 2 (1): 37-45.

15. Depkes RI. (2000). Parameter Standar Umum Ekstrak tumbuhan Obat. Jakarta: Departemen Kesehatan Republik Indonesia

16. Voight R. (1994). Buku Pelajaran Teknologi Farmasi. Diterjemahkan oleh Soendani Noerono Soewandhi. Yogyakarta: Gadjah Mada University Press

17. Fitriasih, Komariyah, S.M., Sandra, Ferry, Pratiwi, N., Hidayati, D.N. (2019). Mangifera indica L. Leaves Extract Induced Intrinsic Apoptotic Pathway in MCF-7 Cells by Decreasing Bcl-2 Expression and Inducing Bax Expression. Indonesian Journal of Cancer Chemoprevention. 10 (1): 1-6. DOI: http://dx.doi.org/10.14499/indonesianjca nchemoprev10iss1pp1-6.

18. Wickenden, J.A., Clarke, M.C.H., Rossi, A.G., Rahman, I., Faux, S.P., Donaldson, K., and MacNee, W., 2003, Cigarette Smoke Prevents apoptosis trough Inhibition of Caspasa Activation dan Induce Necrosis, Am. J. Respir. Cell Mol. Biol., 29:567-570.

DOI: $10.1165 / \mathrm{rcmb} .2002-0235 \mathrm{OC}$ 